\title{
Phosphatase and Tensin Homolog Staining Method
}

National Cancer Institute

\section{Source}

National Cancer Institute. Phosphatase and Tensin Homolog Staining Method. NCI

Thesaurus. Code C122863.

An immunohistochemical technique used to detect the presence of phosphatidylinositol-

3,4,5-trisphosphate 3-phosphatase and dual-specificity protein phosphatase PTEN in a tissue sample. 